\title{
Tobacco-free pharmacies: can we extend the ban?
}

\author{
Mitchell H Katz
}

Like any self-respecting public health official, it was my lifelong dream to be sued by a tobacco company. I got my wish in 2008. At that time I was the Director of the San Francisco Department of Public Health, and we became the first locality to ban the sale of tobacco at pharmacies. ${ }^{1}$ Phillip Morris USA, Inc. promptly filed suit in the United States District Court to overturn the ban.

Their lawsuit claimed that the ban interfered with their first amendment rights to communicate with their customers. But the ban in no way limited advertisements or speech about tobacco within pharmacies; you simply could not sell tobacco products. The court denied their petition. A second lawsuit brought by Walgreen's was resolved with the county broadening the ban to include big box stores and supermarkets that had pharmacies-these stores had not been included in the original ban.

The fact that San Francisco's ban was legally upheld provides a path for other localities to ban the sale of tobacco in their pharmacies. Indeed, in addition to San Francisco, the sale of tobacco in pharmacies is banned in Boston, Newton, Needham, Uxbridge (all in Massachusetts), as well as in the City of Richmond and in the unincorporated areas of Santa Clara, both in California.

\section{BENEFITS OF PROHIBITING THE SALE OF TOBACCO IN PHARMACIES}

There are multiple benefits to prohibiting the sale of tobacco in pharmacies. First, banning the sale of tobacco establishes an appropriate norm as to where tobacco may or may not be sold. Pharmacies are places you go to get healthy; therefore, they should not be selling tobacco.

We know that smoking rates are affected by community norms, which in turn, are influenced by where tobacco is allowed or prohibited. For example, adolescents who worked in smoke-free environments report being less likely to smoke than those who worked at a site without

Correspondence to Dr Mitchell H Katz, LA County Department of Public Health, 313 N Figueroa room 912, Los Angeles, CA 90012, USA; mkatz@dhs.lacounty.gov smoking restrictions. ${ }^{2}$ Also, youth living in towns with strong prohibitions of smoking in restaurants perceived greater social unacceptability of adult smoking than youth living in towns with weaker prohibitions. ${ }^{3}$ By not allowing the sale of tobacco at pharmacies, we establish a clear community norm that tobacco not be sold at places promising health benefits to its customers.

Second, eliminating the sale of tobacco at pharmacies would decrease the density of retail tobacco outlets, which in turn, has been associated with higher rates of youth smoking. ${ }^{4} 5$ As demonstrated by Seidenberg and colleagues in this issue of Tobacco Control, 9\% of all licensed tobacco retailers in the state of Massachusetts are pharmacies. ${ }^{6}$

Third, ease of tobacco purchase may influence smokers who are trying to quit. Consider the abstaining smoker who goes to a local pharmacy to purchase a nicotine patch only to be tempted by the packs of cigarettes on sale. Although the impact of pharmacy tobacco bans on quitters has not been studied, it has been shown that tobacco-abstaining persons living close to a tobacco outlet were less likely to remain abstinent than those living further from outlets. ${ }^{7}$ Also, Clattenburg and colleagues in a Tobacco Control article reported that a substantial proportion of tobacco purchases (11.3\%) at grocery stores were unplanned; smokers who made three or more quit attempts and those who planned to quit next month were significantly more likely to make unplanned purchases. ${ }^{8}$ The same likely holds true for pharmacy purchases of tobacco.

\section{STATE OF TOBACCO SALES IN PHARMACIES}

Unfortunately, as demonstrated by Seidenberg and colleagues, tobacco sales at pharmacies, especially chain pharmacies, are flourishing. The authors found that in Massachusetts, excluding those localities with a ban, $70 \%$ of chain pharmacies had a license to sell tobacco products compared with only $24 \%$ of non-chain pharmacies. ${ }^{6}$ The higher proportion of chain pharmacies selling tobacco than independent pharmacies is consistent with studies of tobacco sales in pharmacies in San Francisco prior to the ban, which showed that the percentage of independent pharmacies selling tobacco declined but the proportion of chain pharmacies selling tobacco remained high. ${ }^{9} 10$ Given that independent pharmacies are increasingly being replaced by chain pharmacies and the chain pharmacies have been resistant to calls from professional pharmacy associations to stop selling tobacco, unless bans are enacted the number of pharmacies selling tobacco will likely grow.

\section{EXTENDING THE BAN}

What will it take to extend the ban of the sale of tobacco in pharmacies to other localities? One thing needed is public support for such bans. The study by Kroon et al in this issue of Tobacco Control is helpful in providing evidence of such support. ${ }^{11}$ The investigators found that $56 \%$ of persons surveyed in San Francisco $(n=198)$ favoured the ban and only $27 \%$ opposed, with the remainder undecided.

At the time the ban in San Francisco was being debated, questions were raised as to whether the ban would harm the profitability of pharmacies because people would have less to reason to shop there. Here too the data from Kroon et al are reassuring. Seventy-six percent of respondents said that the ban made no difference to whether they shopped at pharmacies in San Francisco, and $12 \%$ said the ban caused them to shop at pharmacies more. Certainly, the San Francisco ban does not appear to have hurt the chain pharmacy business. For example, in 2008, there were 57 chain pharmacies in San Francisco with a permit to sell tobacco. In 2013, there were over 70 chain pharmacies in San Francisco. ${ }^{12} 13$ The increase in pharmacies is consistent with the experience of Ontario, Canada, where 2 years after the province banned the sale of tobacco at pharmacies, there was also a net increase in the number of pharmacies. $^{14}$

Ultimately it will take courage of political leaders, buoyed by public sentiment, to extend the ban of tobacco sales at pharmacies. It has been easier to promote bans that limit exposure to secondhand smoke than to promote bans on the sale of tobacco in pharmacies because of the belief that unlike secondhand smoke others are not harmed by where people purchase their tobacco. Although that may be true, the person purchasing the tobacco is harmed, and the goal of an 
effective public health response should be to reduce harm so that people can live the healthiest life possible.

Of note, Koon reports that $88 \%$ of current tobacco smokers had not considered quitting smoking as a result of the ban. I look at it in the opposite way. Twelve percent of current smokers considered quitting simply because San Francisco had banned the sale of tobacco at pharmacies. No one strategy is going to eliminate tobacco use. Banning tobacco sales in pharmacies should be one part of a multifaceted effort to decrease the harm caused by tobacco.

Acknowledgements Steven Schroeder reviewed an earlier version of this manuscript.

Disclaimer The views expressed are those of the author and not necessarily the County of Los Angeles.

Competing interests None.

Provenance and peer review Commissioned; internally peer reviewed.
Published Online First 19 September 2013

Tobacco Control 2013;22:363-364.

doi:10.1136/tobaccocontrol-2013-051322

\section{REFERENCES}

1. Katz MH. Banning tobacco sales in pharmacies: the right prescription. JAMA 2008;300:1451-3.

2. Farkas AJ, Gilpin EA, White MM, et al. Association between household and workplace smoking restrictions and adolescent smoking. JAMA 2000;284:717-22.

3. Albers $\mathbf{A B}$, Siegel $\mathrm{M}$, Cheng DM, et al. Relation between local restaurant smoking regulations and attitudes towards the prevalence and social acceptability of smoking. Tob Control 2004; 13:647-355.

4. Lipperman-Kreda S, Grube JW, Friend KB. Local tobacco policy and tobacco outlet density: associations with youth smoking. $J$ Adolesc Health 2012;50:547-52.

5. Novak SP, Reardon SF, Raudenbush SW, et al. Retail tobacco outlet density and youth cigarette smoking: a propensity-modeling approach. Am J Public Health 2006;96:670-6.

6. Seidenberg A, Hong Liu JU, et al. Availability and range of tobacco products for sale in Massachusetts pharmacies. Tob Control 2013;22:372-5.
7. Reitzel LR, Cromley EK, Li Y, et al. The effect of tobacco outlet density and proximity on smoking cessation. Am J Public Health 2011;101: 315-20.

8. Clattenburg EJ, Elf JL, Apelberg BJ. Unplanned cigarette purchases and tobacco point of sale advertising: a potential barrier to smoking cessation. Tob Control 2013;22:376-81.

9. Eule B, Sullivan MK, Schroeder SA, et al. Merchandising of cigarettes in San Francisco pharmacies. Tob Control 2004;13:429-32.

10. Schroeder SA, Showstack JA. Merchandising cigarettes in pharmacies: a San Francisco survey. $A m$ $J$ Public Health 1978;68:494-5.

11. Kroon L, Corelli R, Roth A, et al. Public perceptions of the ban on tobacco sales in San Francisco pharmacies. Tob Control 2013;22 369-71.

12. http://www.walgreens.com/storelistings/storesincity. jsp? state $=$ CA\&city $=$ San\%20Francisco. (accessed 28 Aug 2013).

13. http://www.cvs.com/stores/cvs-pharmacy-locations/ California/San-Francisco. (accessed 28 Aug 2013).

14. Taylor MC. Banning cigarette sales in pharmacies does not result in pharmacy closures, 1997.

Physicians for a Smoke-Free Canada Web site. http:// www.smoke-free.ca/pdf 1/pharmacy.PDF. (accessed 20 Aug 2013) 